\title{
Bóg zgody, zemsty, sprawiedliwości - o poezji rokoszu Zebrzydowskiego
}

\author{
Iwona Maciejewska
}


naPDS Seria XII 2006)

\section{Iwona Maciejewska}

\section{Bóg zgody, zemsty, sprawiedliwości - o poezji rokoszu Zebrzydowskiego}

\footnotetext{
$\mathrm{C}$ laude Backvis w swe Panoramic poezii polskicj okresu baroku wyodrębnia wśród wiodących kręgów tematycznych poczjç obywatelską, wskazując jednocześnie, iz hadacz dawnego piśmiemictwa nie nozze przejść obojętmie wobec ,dziesiątków tysięcy wersów, które należy zaliczyć do tej kategorii". O popularnósci literatury komentıjącej bieżące wydarzenia decydowal oczywisty fakt:

w dawnej Polsce namiętność do polityki zajmowala niezmiennic i w zasadzie powszechnic, przynajmniej w środowisku szlacheckin, pierwsze miejsce w hierarchii zainteresowań $|\ldots|^{\prime}$.
}

Trudno więc wyobrazić sobie, by tenn rys nentalności nic znalazl szerokiego odzwierciedlenia w ówczesnej praktyce literackiej. Skali zjawiska dowodzi niezastapiona do dziś wiclotomowa monografia Juliusza Nowaka-Dlużewskiego, poświęcona okolicznościowej poezji polityczncj, poszukıjąca początków tego typu piśmicnnictwa już średniowieczu. Jednakze, jak słusznie zauważa Backvis, dopiero wzrost znaczenia politycznego i kulturalnego szlachty mógł w sposób decydujący wplynąć na dynamiczny rozrost literatury politycznej, który przybiera z czasem gigantyczne rozmiary². Nowak-D)hizewski wyraziście wskazuje moment historyczny, w którym po raz pierwszy stykamy się na niespotykaną dotąd skalç z zalewem okolicznościowego piśniennictwa komentującego biezazce wypadki w państwie. Jest to okres rokoszu Zebrzydowskiego, bądź jak chcą niektórzy badacze, sandomicrskiego. Ani lata sejmów egze-

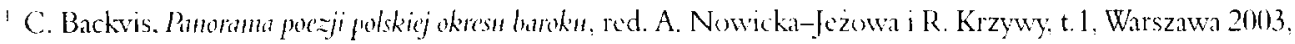
5. 331

2 Zob. ibidcm, s. 332. 
kucyjnych, ani pierwsze bezkrólewie nie zrodziły tak obfitego plonu ${ }^{3}$. W tcj masie różnorakich tekstów ${ }^{\dagger}$ ścieraly się pełne emocji głosy dwóch antagonistycznych obozów - króla Zygmunta III Wazy i jego kamaryli oraz prorepublikańskiej, częstokroć innowierczej, szlachty, przeciwnej planom reform prowadzących do wzmocnienia pozycji władcy. Nie bez znaczenia były też liczne wypowiedzi antorów, którzy nic popicrali w sposób wyraźny żadncj ze stron, lecz z zaniepokojeniem obserwowali rozwój wypadków prowadzący do bratobójczego konfliktu. Choć krótka wojna domowa nie przyniosła wielı ofiar i jakichśs szczególnych zniszczeń, była jednak zgubna w skutkaclı, gdyz, mówiąc słowami Backvisa, „pozostawila tylko zwyciężonych”. Król, pozorny wygrany, musiał wycofać się ze swych planów reform, republikanie zaś

w momencie podjęcia dzialań skompromitowali siç krę̧tactwem, próbując maskować swoje niezdecydowanie czcza gadanima”

Największą stratę poniosła Rzeczpospolita, gdyż trzyletnia burza polityczna nie zrodziła zadnych konstruktywnych efektów.

Zaistniałe wypadki mialy też imne konsekwencje - odcisnęły istotne piętno na świadomości ówczesnej spoleczności. Dawali temu wyraz twórcy literatury, dla których czasy, w jakich przyszlo im żyć, były zbyt trudne i smutne. Tę nutę przygnębienia wielokrotnie odnajdzicmy w piśmiennictwic rokoszowym, i nic ma tu większego znaczenia, którą ze stron konfliktu popieral autor danego utworu".

Nie zatrzymując się dłużej nad politycznymi czy światopoglądowymi konsekwencjami dramatycznych zdarzeń z początku XVII wickı, warto blizej zagłębić się w powstałą wówczas bogatą literaturę, bezpośrednio związaną ze starciem obozu królewskiego i jego republikańskich przeciwników. Miala ona na celu nie tyle szczegółowe opisanie konkretnych faktów, ile przede wszystkim otwartą agitację, przekonanie wahających się mas szlacheckich do określonych poglądów. Przypomnijmy znany fakt, iż walkę polityczną przeciwnc sobie strony prowadziły w warunkach, gdy nie istniala jeszcze prasa w dzisiejszym rozumieniu? ${ }^{7}$. Wprzęgano więc literatırę w słuzbę polityki, a po wypracowane przez wieki formy artystycznego wyrazu sięgali zarówno uznani wówczas twórcy. jak i szlacleccy domorośli grafomani, którym Bóg poskąpit talentu, a obdarzył chęcią publicznej wypowiedzi. Nietrudno więc zrozumieć badaczy przedmiotu, którzy częstokroć zastanawiają się nad interesującą nas tu poezją polityczną: czy to jeszcze literatura, czy tylko wierszowana publicystyka?

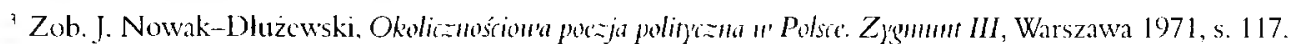

${ }^{4}$ Cennej edycji tego piśmicmictwa. cloć nic bez pewnych braków, dokonal Jan Czubck, Pisma polityczm z czasón rokoszll Zébrzydurskicgo (1606-1608). t. 1-3. Kraków 1916-1918.

C. Backvis, op. cit.. s. 52 .

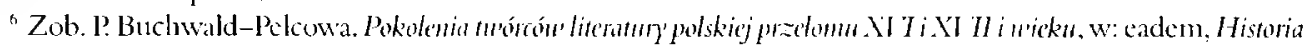
literatury i historia ksiażi. Kraków 2005, s. 225.

'Zob. J. Pelc. Tekst literacki u' okresic' sturopolskim. .,Przeglad H Hunanistyczny“ 1959. nr 3, s. 78-79.

${ }^{x}$ Bywa. że micwają na temat konkretnego utworu odnicnuc zdanic, czego dowodem mogą byé polemicznc uwagi w wyżcj wspomniancj pracy J. Nowaka-Dhızewskiego. który nicjectnokrotnic nie zgadza się̧ w pełni 
Bóg zgody, zenusty, sprawicdliwości - o poczji rokoszu Zebrzydowskiego 37

Lecz tej masy piśmiennictwa nic należy lekceważyć, gdyż jak zauważa Backvis, mnogość tych wypowiedzi sprawiła, iz

zadzialo dobroczynne prawo konkurencji. Okazalo siç, ze nic wystarczy zgromadzić garść naprawdę celnych czy choćby rzekomych argumentów, by przyciagną̧ć i utrzymać w napięciu atakowaną ze wszystkich stron uwage czytelników".

Należało ich zaskoczyć i zainteresować, i w tym celu autorzy sięgali po przeróżne rozwiązania. Nie zawsze efekty tych poszukiwań są dziś dla nas budıjące, ale na pewno nie można odmówić zaangażowania i pomyslowości ówczesnych polemistom.

Okolicznościowa poezja polityczna to zjednej strony żywe, aktualne wydarzenia, materia dziejów domagająca się komentarza, a z drugiej zaś pewna wypracowana konwencja, do której przyzwyczaiła odbiorce tradycja literacka, jego czytelnicze obycie, szkolne wyksztalcenie. Oba te elementy decydowaly o sile oddzialywania danego tekstu. Bywalo, że autora stać bylo tylko na przewierszowanił wyliczankę swych argumentów, tak jak w utworze Traba wohnósi, w którym skrupulatıie wymicnia siç wszystkie urazy szlacheckie do króla, ale o skuteczności agitacyjnej tejże rymowanki Nowak-Dlużewski wyraża się z wielkim przekąsem"'.

Nie komentując słusszności argumentów z.walczających się wzajemmie stron, warto tylko wspomnieć, jakimi grzechami obarczano niepopularnego wladcę. Mówi to nam wiele o ówczesnej mentahości szlacheckiej spoleczności i jej widzeniu rzeczywistości. Obok więc poważnych, choć niesprecyzowanych zarzıtów o zdradę, niewypehnianic elekcyjnych zobowiązań, brak troski o panístwo i uwikłanie Rzeczypospolitej w zewnętrzne konflikty w innię wlasnego, dynastycznego interesu, wymawiano Zygmuntowi III otaczanie się cudzoziemcami, ślepe posłuszeństwo znienawidzonym jezuiton, .niecharześcijańskie”, jak je określano, malzeństwo z siostrą swej zmarłej pierwszej zony, zaniedbywanie królewskich obowiązków na rzecz podejrzanych i niegodnych rozrywek w rodzaju alchemii, a wreszcie sktonność do rozpusty ${ }^{11}$. Zgodnic z narastającą wśród potomków Sarmatów niechęcią do tego, co obce, krytykowano króla nawet za jego cudzoziemski strój ${ }^{12}$.

Ówczcśni przcciwnicy wladcy i jego popleczników bardzo często sięgali po formę paszkwilı, gdy zaś brakowało konkretnych argumentów, clı̨tnie wykorzystywali inwektywę, tak znanniennią dla literatury polemicznej. Obóz królewski także nie pozostawał dluzny. Słowne

zoccnami poszczcgólnych tekstów formulowany'ni przzz Alcksandra Bruckucra w jego Stmdiud had literaturą "ricku. Xl H. Kraków 1917.

"C. Backvis, op. cit., s. 332

${ }^{10}$ Zob. J. Nowak-Dluzewski. op. cit. s. 120-121.

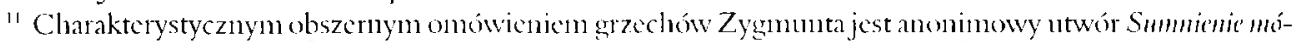
"'i, szczególnic podkreślający zgrozę królewskicj rozpusty i sprawç jego bulwersujacegro matzeństwa. Zob. Pisma polityrzu' z casón rokoszn Zelwzydow'skicgo, t. 1, wyd. I. Czubck, Kraków 1916. s. 12-24. Wszystkic cytaty poczji rokoszowej będa pochodzić z tegoż uydania, unucjscowicnic podaję po przytaczanych fragnentach.

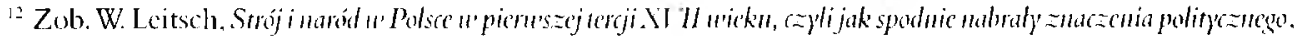
.Barok. I Iistoria - Litcratura - Sztuka” VL/2. 1999. s. 18-19. 
starcia pełne są określeń mających zdyskredytować, ośmieszyć i obrazić wroga politycznego ${ }^{13}$. Padają dosadne epitety i porównania, dotyczące moralności, zdolności intelektualnych przeciwnika, jego pochodzenia, czy wreszcie wyglądu zewnętrznego lub nagannych upodobań (Na senatory; Przemou'a do panón'senatorón) ${ }^{1+}$. Przedstawieniu w nickorzystnym świctle bądź zwyklemu ośmieszeniu służą pojawiające się motywy zwierzęce, napotykany więc tu znane wielowiekowej tradycji polemicznej ${ }^{-15}$ osly, wilki, nicdźwiedzie, lwy, smoki, liszki, wieprze, barany, a z drugiej strony symbole niewinności - owieczki czy lanie, uciemiężone przez podstępnego wroga. Czasem autor pokusil się o bardziej wyszukane skojarzenia, nic zawsze z dobrym artystycznic skutkicm, jak choćby w paszkwilı na Stanisława Żółkiewskiego, gdzie hetman jest porównywany kolejno do jelenia, konia, orla, lasicy, żurawia, gryfa, jaskólki itd., wszystko po to, by poprzez paralelę zachowań lub kontrast pokazać niecna zdradę dawnego sprzymierzeńca rokoszu (Pinn Źótkien'skiénu, hetmanou'i polnemun) Wśród określén często też występował diabel, bądź jako człon porównania, bądź inspirator działań przeciwnikit ${ }^{16}$.

Wake z adwersarzami politycznymi służyły nie tylko dosadne określenia czy przejrzyste w intencjach skojarzenia. Wykorzystywano znane przyslowia, wykazywano się inwencją slowotwórczą, nazywając rokoszan up. „niespokojniczkani”, „zabawniczkami” (Przyjacicl do przyjacicla po rozprauic pod Janou'cem, s. 129), a próżnujących ludzi Dworu "darmojadami”, "głaszczoluchami” i „wyzmikultlami” (J. Jurkowski, Led uzbudzon\}', s. 59). Aby perswazja byla skuteczna i nienużąca, sięgano po różnorodne formy gatunkowe. Wśród poezji rokoszowej obok krótkich pobudek, pieśni, ckscytarzy, zuajdziemy między innymi raki, echo, utwory oparte na rozbudowanej alegorii, dialogi, listy, skargi lamentı1ącej i chorej Rzeczypospolitej, czy wreszcie różnorodne nawiązania do form piśmiennictwa religijnego ${ }^{17}$.

Wielorakość rozwiązań niosla za sobą zróżnicowanie nastrojów tej poezji. Obok zjadliwej ironii i szyderstwa - szczere zaniepokojenic, gorycz i rozczarowanie; obok optymistycznej wizji przyszlości - narzekanie na upadek obyczajów i tęsknota za utraconym (z winy obywateli bądź niekorzystnego układu planet) złotym wiekıem i dawną świetnością państwa (Jan Jurkowski, Led uzbudzony; Marcin Blazewski, Thumacz rokoszon'y pouratu mskiego; Marcin Paszkowski, Wyktad bogin stou'ieniskich). Z jednej strony pomysly orygginalne i świeże, z drugiej konwencjonalne skargi na zmienność losu, przykłady państw, które upadły przez wewnętrz-

\footnotetext{
"Alcksander Wilkoń zwraca uwagg na zauważalny w baroku wzrost stylu paszkwilanckicgo: .Dla paszkwilanta kazdy chwyt jest dobry. poszukuje on sformulowan szczególnie ekspresywnych, przejętych z mowy potocz-

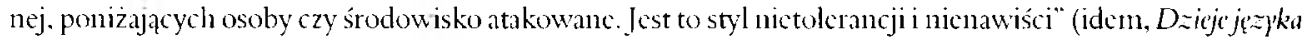
art'styes

it Byly to metody doskonale znane wszelkicgo typu polemice, w tym oczywiścic toczącej siç walce zwolenni-

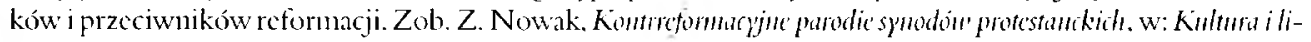
teratura dauencj Polski. Studia, Warszawa 1968, s. 21+-25t.

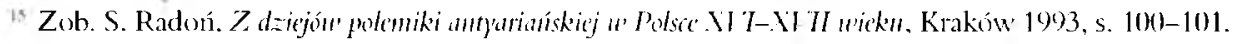

${ }_{16}$ Por ibidem, s. 94-95.

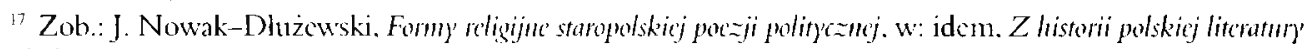
i kultury, Warszawa 1967, s. 167-181.
} 
ną niezgodę ${ }^{1 \times}$, w tym do znudzenia powtarzany casus Węgier ${ }^{\prime \prime}$, wreszcie czytelne aluzje literackie, między innymi do Trenón' Jana Kochanowskiego.

W naszych rozważaniach baczniejszą uwage pragnienny zwrócić na jeden bardzo istotny rys poezji rokoszowej, który powraca w wielı utworach bez względu na ich formę i wymowę ideową. Otóż można stwierdzić, iz jest to poezja z Bogiem w tle. Pośród potoku stów, które mają wyrazić przeróżne emocje, często również te bardzo negatywne, stale pojawia się słowo „Bóg” odmieniane na wiele sposobów. Jakby Stwórca mial być dla piszącego jeszcze jednym niepodważalnym argumentem w prowadzonej agitacji, bądź kiedy indziej jedynym możliwym ratunkicm w sytuacji narastającego zagrożenia.

Obecność Pana Wszechświata jest w poezji rokoszowej zaznaczona w różnym stopniu. Bywa, że autor przywoluje Jego imię jedynie w ekspresyjnych zwrotach w rodzaju: „prze Bóg”, „dla Boga” itp. Ale znacznie częściej zdarza się, iż Stworzyciel jest dla koncepcji calego utworu personą niezbędną. Poeci stawiają Gow wielu rolach i wiele od Niego oczekują. Nie są to bynajmnicjjednolite oczekiwania. Zważywszy na sytuację, w jakiej znalazła się wówczas ojczyzna, nie dziwią nas teksty, w których Bóg jako milosierny Pan i Ojciec proszony jest o ulitowanie się nad nieszczęsnym krajem, pogrążonym w domowych waśniach:

Ratuj Ty sam nas, Boze lutościwy!

13o jeśli Twego nic będzic ratunku,

Zginicny zgola i samegro gruntu,

A utraciwszy ojczyznę swą milą,

Już nie będziem mieć nigdy taką inna

(Z.goda $i$ żatosna przestroga, s. 203).

Tymi stowami wola do Wszechmocnego anonimowy twórca Zgody' $i$ żatosnej przestrogi, a podobne stormulowania znajdziemy w wielı tekstach o charakterze elegijnym (Elegia postón' splondron'anych od pogan; Elegia Korony Polskiej 160)6; Zatosme narzekanie Korony Polskicj Jana Danieckiego; Lament ̇atosny Kornly Polskicj Wawrzyńca Chlebowskiego).

Wiara w Boze milosierdzic plynie z niejednokrotnie wyrazanego w rokoszowej poezji przekonania, iz Stwórca jest bezwzględıym zwolennikiem zgody i pokoju:

Tam Bóg sam blogoslawi, gdzie zgoda panuje,

Jego to nawiększy dar: któremu daruje

Królestwu, tam rząd wielki, cnota, sprawiedliwość,

Obfituje pobożnośc, nie ma tam micjsca zlość

(Upommienie Koron)' Polskicj. s. 325).

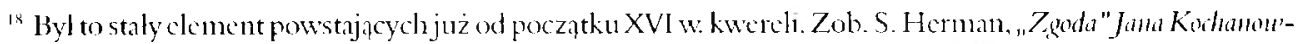

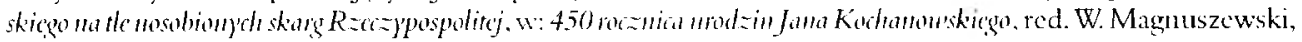
Ziclona Góra 1985, s. 83.

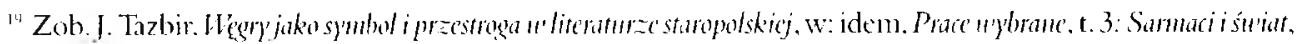
red. S. Grzybowski, Kraków 20191. s. +30$)+53$.
} 
Jednak równie często autorzy proszą Boga o coś zupetnie innego niż zgoda i pokój-proszą ... o zemstę i karę z wiarą w slusznność swych błagań. Bywa, że obiekt tej zemsty jest wymieniany wprost:

Przeslawna krew rycerska ludu ukrajnego,

Żałośnic narzekając na króla polskiego,

Wola od Boga pomsty $|\ldots|$

Zemści się, Boże, krzywdy, strąć go ze stolca jego,

By w krótkim czasie doznał więzienia ciężkiego,

A nas, nędzne sieroty, sam racz wyswobodzić

Wszechmocną swą prawicą, a jego racz zgładzić

(Elegia postón' splondrouranyéch od pogan, s. 1-2).

Modlitwie o zemstę towarzysza jawne złorzeczenia, oczckiwania jak najgorszego losu dla przeciwnika, „odszczepieńskiego gminu przeklętego”, które, co ciekawe, sąsiadują z wychwalaniem mikej Bogu zgody i prośbami o laskę dla „prawowicrnych" (Lanent na sektę rokoszaniska, s. 218). Domaganie się srogicj kary przychodzi autorom z czasów rokoszu latwiej niż blaganie o miłosierdzie. Dotyczy to zwłaszcza tych, którzy wyraźnie opowiadają się po którejś ze stron. Można to zacietrzewicnic zobaczyć w popularncj wówczas i potem naśladowanejeㄹ parodii Modlitu'y Paniskiej, której adresatem jest Zygmunt III Waza:

Ojcze nas, królu polski, który mieszkasz w Warszawie,

U nas $[w]$ niedobrcj slawie!

Święć się w Szwecyej imię twoje,

Gdzie są z dawna rwe pokoje,

Przydź do królestwa [twego] szwedzkiego,

A zaniechaj polskiego i księstwa litewskiego.

Bądź wola twoja w Wandalech, jako pierwiej byla,

Gdzie[ś] dobrych śledzi mial obfitość siła.

Chleba naszego powszedniego

Zbawileś nas za panowania swego.

Odpuść nam lanowe, poborowe, czopowe,

Bo bardzo już u uas są rzeczy nie nowe.

I nie wwódź nas na pokuszcnic na wojnę z Szwedami,

Bo jej dla ciebie doma dosyć many.

Ale nas zbaw ode wszego zlego,

A sam idź prędko do Boga wszcchmogącego,

Abowiem twoja moc nad nami,

Lepiej, niz radzić o nas z Jezuitami.

Amen (Pacierz do Króla Jegomości, s. 34). 
Czyż nie jest znamienne to, ze wśród amplifikowanych wersów modlitwy zabrakło znaczących slow: ,jako i my odpuszczamy naszym winowajcom"? ...

Obie strony konfliktu zakładaja, że Stwórca doskonale wie, kto w tym sporze ma rację. To przekonanie wiąze się z równie powszechną w tej poezji wizją Boga jako sprawiedliwego Sędziego, nicprzckupnego, który może czasem ociąga się z wymierzeniem zastuzoncj kary, to jednak nigdy w swych wyrokach nie blądzi. Anominnowy autor Wotum Filopolitesa Pran'dzickicgo przekonuje siebie samego i zwolenników rokoszu, prawie jak zawiedzione dziecko, że przeciez:

Bóg nic jest taki, aby sprawicdliwej rzeczy

Mial odstapić, owszem ją ma na dobrej pieczy (s. 293).

W ten sposób pokrywa swe rozczarowanie spowodowane, jak siç domyśla Jan Czubek, klęską pod Guzowem.

Właściwy osąd rozgrywających się wypadków ulatwia Bogu Jego niezmierzona mądrość i pozycja wszcchwiedzącego Obserwatora. W takiej roli stawia Go między innymi autor utworu Summicnie móuri, skierowanego do króla. W tckście, jak swoisty lejtmotyw, uwypuklony anaforą, powraca obraz Stwórcy, który wszystko widzi, każde najmniejsze przewinienie władcy, więc według poety to już najwyższy czas na spowiedź i mocne postanowienie poprawy:

Bój siç̣ Boga, [na] jego uważaj snać sądy,

Wejrzyj w s[w]oje summienie, w twe królewskie rządy,

Godne we wszem przygany i pożalowania (s. 16).

W wypowiedziach zwalczających sic̨ obozów widoczne jest przekonanie, ze winni są oni, a my to ostatni sprawiedliwi. Z jednej więc strony zashuzona kara czeka Stanisława Zólkiewskiego, „rozlewcę krwi braterskiej” (Ekscytarz, s. 31)8), czy samego Zygmunta III, który za sprawą Bożego wyroku rychle ,między trupy będzie policzony” (Pieśí o rokoszu nieszczesnym, s. 271). Za to walczącym po waściwej stronic - bohaterom Nagrobka pobitego o l'olnosic rycerstu'a polskiego pod Guzourem - Bóg w nagrodę zgotowat koronę w niebie. Zwolennicy króla nie pozostaja przeciwnikom dlużni, wskazując na wołające o pomstę grzechy buntowników: pychę, upór, prywatę, sprzeciw wobec prawowitego władcy, hardość, swawolę prowadzącą do krzywdy niewinnych ludzi, naruszanie świętej zgody poprzez nieustanne spory:

Pański nas ręka dotknç̣̂,

Ozdobyć, Polsko, ujęła.

Wiary, męstwa i stalości.

Rokosz powód ku żalości. [...]

Hardość krzywdy i swąwola

Bóg placi ciężką niewolą (Laminnt ma sektę rokoszańską, s. 205). 
Jednym z najczęściej wymienianych grzechów, który miał Stwórcę szczególnie rozgniewać, jest oczywiście odstapicnie od prawowitej wiary katolickiej, odziedziczonej po cnych przodkach (Zgoda $i$ żatosna przestroga). To zarzuty pod adresem innowierców, licznie reprezentowanych wśród rokoszan. Odszczepieńcom nie szczędzi się ostrych słów i zlorzeczeń:

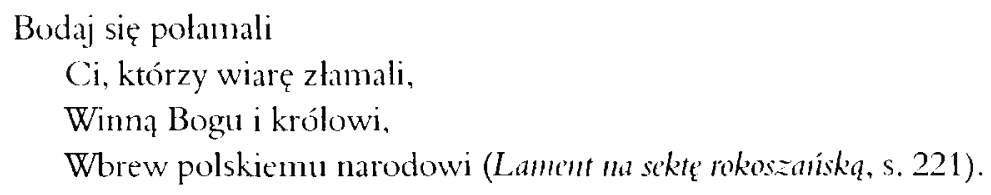

I Ieretycy są gorsi od diabła, ale jeszcze wiçkszą hańbą okryli się katolicy, którzy im pomagają. Za karę Bóg z pewnością wytraci ich w pierwszej kolejności. Pisarze broniący pozycji katolickiego duchowieństwa przekonują, że obwiniać sługi Boże, to „rzecz barzo szkaradna”, bo to jedynie oni moga, jak Mojzèsz, uchronić nas przed narastającym gniewem Boga (M. Blażewski, Thumacz rokoszou'y', s. 174-175). W alegorycznym utworze Et enunt novissima peiora prioribus uosobiona, znajdująca się w oplakanym stanie, Respublica wola do swych niewdzięcznych synow o pokutę i wdzianie wlosicnnicy. Wszak wystapili oni nie tylko przeciw przelożonemu, czyli królowi, ale i najwyższemu Władcy w Niebiosach. Maluje ona obraz lBoga ogarniętego furią i wypuszczającego zapalone gniewem strzaly. Gniew to uzasadniony, bowiem ludzie targnęli się na największe świętości, a zadowolony Atheismus triumfuje.

Jakby w odpowiedzi na tę wizję w prorokoszowym Ekscytarzl znajdıjeny stwierdzenia, że prawdziwa pobożność to nie ta, której broni obóz królewski. Ona już dawna z Polski odeszla, panuje jedynie makiaweliczna obluda, która występuje przeciwko prawdziwej wolności, a broni tyraństwa.

Przeświadczenie o nieuchromności Bożej kary jest w tej poezji dość powszechne, również w tych tekstach, które nie opowiadają się wyraźnie po którejś ze stron. Polacy rozgniewali Pana, konsekwencje tego gniewu są w pełni zasłıżone ${ }^{21}$. Rzeczpospolita - Sarmacja, przez Boga wybrana i umiłowana, zostala przez Niego szczodrze obdarowana (W. Chlebowski, Lament Zatos $)^{\prime}$ Korony Polskicj), a komu wiele dano, od tego wiele się wymaga. Dawna świetność państwa przeminęla z winy samych jego obywateli, a ..Lech wzbudzony” w poemacie Jana Jurkowskicgo w tragicznej tonacji maluje wizję XVII-wiecznej Polski,jakże odległą od tej sprzed wicków. Anonimowy autor Upominania Korony' Polskiej stwierdza, iż z powodu haniebnej niezgody bliski jest zapowiadany dzień Sądu Ostatecznego i to już najwyższa pora, by się opamiçtać.

Według Marcina Blażewskicgo żclazne wicki zrodzila „wolność żelazna”. Ona to „Rzeczpospolitą sobą przywaliła" (Thumacz rokoszou' ', s. 160) i doprowadzila do bratobójczych waśni, których czuwający nad nami Bóg na pewno nic pochwala:

${ }^{24}$ Zob. K. Obremski, "Psalmodia Polska". Tray strdia mad pormatem. Torun 1995, s. 133-134 i innc. 
Gidzie znak wygranej bitwy, gdzic dany przykować?

Podobno z braterskicj krwie chcemy tryumfować.

Do kogo powiązane jerice powiedzicmy,

L.ub nagrodę zwyciçstwa od kogo wéźmiemy?

Od Boga? - tam przeklçtej zapłaty czekamy?

Bo ni Boga, ni prawa, ni pana nie many.

Wiarę Bogu, wiarçśny i prawom zlamali,

Wolnością naszą z brzegów cnotyśmy wylali.

Prawdéc rzekę: z cnotą siç wadzą w ten czas sprawy,

Gdy śmialością, niè męstwem, nabywamy sławy (s. 162).

Polacy ukuli ze swej wolności żelaznego wolı, jak Izraelici zlotego ciclca, i jemu oddaja teraz pokłony. Choć Backvis uznaje ten ponysł za artystycznie dziwaczny ${ }^{22}$, to idąc za Brïcknerem, chwalącym utwór, warto docenić dostrzęzenie przezz poetę realnych zagrożeń plynących z kultu szlacheckich swobód ${ }^{23}$.

Jednak takie myślenie pojawia siç w analizowanej twórczości rzadko+ Bliższy ogólowi byl pogląd, że choć zgrzeszyli, to przeciez Bóg czuwa nad Swymi wybrańcami, opickuje się Rzeczpospolitą i jej idealıym ustrojem. Kazdy stawia Wszechmogącego po stronic własnych racji. Dlatego wedlug rokoszan libertatis vindex srogo pokarze króla tyrana i wesprze działania jego przeciwników, strzegacych swych praw ${ }^{25}$ :

Racz ten rokosz na dobre obrócić,

A zdrajcom jego żywota skrócić (Elegia Korony Polskicj 1606, s. 37).

Obóz królewski zaś widzi w Bogu Obrońcę polskiego Dawida - niéwinnego władcy (Piosnka nabożna za Króla Jego Mitośi i Rzeczpospolita), o którego krzywdę Pan wstawil się bezpośrednio i doprowadzil do ngody pod Janowcem. Za to:

$\because$ C. Backvis. op. cit., s. 334

ZZ oceną Brucknera częściowo zgadza siç Nowak-I)luzewski. chwaląc patriotyezua postawę Blazewskiego. shusznuś jegotez i niçposzlakowana polszczyzuç wicrsza. a krytykując go za oderwanz od zycia topikę ijej rétoryczne cluwyty" (Okolic nositou'a poeza polit)

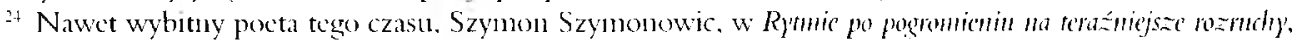
ımmarkowanie regalistycznyn i irenistycznym w tonic, broni złotej wolności i intencji rokoszan, porównując szlachcica polskicgo do konia, którym nalezy kicrowac lagroduic. gdyz:

Ciz̨śsicj koni. w trardej krydze cleodzić nauczony.

Jaźdźca zmiata. zaś w biegu munsztuk pozwolony

Lacnicj utrzyma, niźli wodze mocno ję̧e.

Próżno wçdzidlo wściąga już raz na kich wziçte.

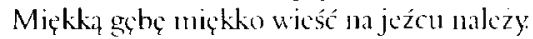

Wolny lud wolno prowadź: dobrze on policży

I bez presta. [... (s. 320)).

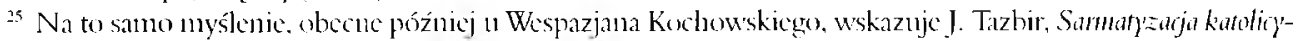

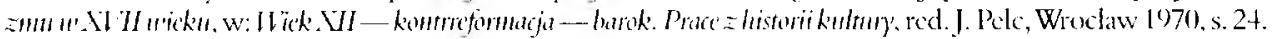


Dziçkuj, Polsko, Bogu z Litwą.

Ze się to stalo nie bitwą (Druga pieśń o rokosie, s. 127).

Autorzy wielu utworów pragną̧ uczynić Wszechmogącego bezpośrednim uczestnikiem wypadków, stąd tytułowanie Go wodzem, sternikiem, zbroją, hetmanem. W jednym z tekstów Jana Krajewskiego Najwyższy jawi nam się niemalże jako dens ex machina. W bitwie pod Guzowem:

Nie chcial Bóg wiclkiej zguby narodı swojego,

Wypuścil wiatr, że nie znal i jeden drugiego.

Nicmało ich cudownie mężnic siç potkało,

A na placu pobitych niewiele zostało

(Nenia na zbiegta zode z Polski utrapionej, s. 280).

Stwórca, opickując siç swym ludem, nie dopuścil do krwawej jatki, a zeslany wiatr i towarzysząca mu kurzawa z.musila wojska do rozpierzchnięcia się. Wedłıg Nowaka-1)łużewskiego w rzeczywistości znaczna część rokoszan, na czele z Zebrzydowskim, naciskana przez wojska prokrólewskie, rzuciła się po prostu do ucieczki. Jednak Krajewski, mimo iż był zwolennikiem Zygmunta III, chciał zaoszczędzić swoim ziomkom realistycznego opisu ich niechlubnego odwrotı, stąd pomyst owej Buskiej interwencji ${ }^{26}$.

Bezpośredniego zaangażowania Pana Nicbios w rozwój wypadków dopatrywal się też wcześniej Jan Daniecki w Żatosnymu narzekanin Korony' Polskiej, kumentując ugodę janowiecką:

Kiedy Pan milosierne spuścil oko swoje,

A obaczyl zemdlone wszystki czlonki moje,

Które spólnie z synami mialy się rozsiewać

Po ziemi, a one krwią żałosną oblewać;

Wstargnąl wodze obojej ich zapalczywości,

A rozbil, jako clmurę, śmierci zlej srogości

I sanze sposób podat, czemuby nie sprostal

Był w ten czas nikt, iz oni i pan przy swym zostal (s. 135).

Tylko Bóg mógł sprawić, by wilk był syty i owca cała. Ale dalsza część lamentu pokazuje, jak kruche by to to pojednanie, nad czym irenistycznie nastawiony Daniccki wielce ubolewa. Znowu więc po raz kolejny zwraca się o ratunlek do Boga:

Boże i obrońco mój! Swoję świętą strażą

Miej nad nami, a ludziom chciwym niepokoju

Uzycz, użycz cichego twej dobroci zdroju.

Jeśli ukrzywdzeni w czym, wszak w Twoich jest świętych

Rękach serce królewskie, aby swych zaczętych

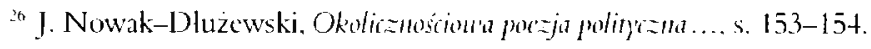


Spraw do skutku niezgoda nie mogla przywodzić;

Wlej w nie takową mądrość, aby mógl dogodzić

I onym i majestat nie był obelzony

Twój, na którym, o Pinie, on jest posadzony (s. 142-143).

Trafinym komentarzem do tego utworu są stowa Nowaka-Dhuzewskiego, który stwierdza, iz:

powszechne było u poetów i publicystów okresu rokoszu przekonanie, że każda ze stron wojujących, zarówno regalisci, jak i rokoszanic, miała rację. [...] Kazdy z nich tkwi właściwic w ideologii szlachty, z której wyszedł i z którą się solidaryzuje,

i w rzeczywistości brakuje tu głębszej refleksji 11 ad tym, co naprawdę jest dobra dla państwa ${ }^{27}$.

Widać tę postawę również w utworach powstałych już po pogodzeniu się króla z Zebrzydowskim, gdzie z radością pisze się o zakończeniu konflikt11, zbyt szybko przechodząc do porządku dziennego nad zaistnialymi wypadkami, jakby przyczyny waśni i rozliczne grzechy, nad którymi jeszcze przed momentem się rozwodzono, nagle zniknęly jak za dotknięciem czarodziejskiej różdżìi ${ }^{2+}$.

Miejsce kornych blagań o z.mitowanie, nawoływań do pokuty i poprawy zajmują radosne dziçkczynienia za to, że Pan jak „ociec przyjunuje swe syny, odpuszcza winy” (A. W., Gratulatio, s. 344). Wiçkszość autorów to właśnie Bogu przypisuje, iż nastal „pokój zdrowy” (Kasper Miaskowski, Post nebula Phocbus, s. 348) i po słuszncj karze czekaja nas lepsze czasy. Marcin Paszkowski wierzy nawet w ponowny powrót złotego wieku i snuje optymistyczną wizję jednej owczarni pod jednym pasterzem bez kłómi i waśni (W Kkład bogiń stourieniskich). Z kolei Stanislaw Grochowski zakoniczony spór podsunow uje retorycznym pytaniem, czy istnial kiedyś naród bez „wnçtrzncj niezgody?” (Na dzicri piqukou”’, s. 347). Najważniejsze, że Bóg doprowadził wszystko do szczęśliwego finałı.

Nie można dziwić się tej radości z ostatecznego porozumienia, ale też nie wolno zamykać oczun ma prawdę historyczną. Wiadomo, że owa opicwana z entuzjazmem zğoda była wlaściwe wymuszona klęską pod Guzowem, że Zebrzydowski bard zo długo ociągał się z przeprosinami króla, a nastroje szlachty dalekie byly od uspokojenia. Zresztą uważnie śledząc teksty opisujące zakoniczenie konfliktı, znajdziemy rysy na tej z trudem odbudowanej konstrukcji. Jan Krajewski w utworze Zgoda i pokój, komentując z radością pomyślny obrót wydarzerí, nie zapomina dopiec niedawnym buntownikom:

\footnotetext{
$\Rightarrow$ Hidchls. s. 163-164.

${ }^{2 x}$ I Ienryk Wisner zwraca twage na fakt, iz literackic colna tego konfliktu nad wyraz szybko tcichly, gdyz ..ani zwycięzcy nic chcicli slawić zuycięstwa odniesionc gow bratobójczym boju. ani zwyciçżcni narażá siç na zarzut, że wystapili przeciw prawowitemu wadcy" (idem. Rokose Zebroflowskices, Kraków 1989, s. 77).
} 
U których bojaźní Boża za nic dotąd była,

Ale krzywda, placz ludzki, sromota im miła.

Dziś in zgodą wykole wesoly czas oczy,

A icl karki ku ziemi Bóg gniewem przytłoczy.

Każdy dobry raduj się, żeś w liczbie zlośliwych

Nie byl, aniś się karmil płaczem nieszczęśliwych.

Najdzie Bóg sposób taki, że złym ich zlość zgani;

Hardość ich nie ratıje, będzie kazdy tani (s. 355).

Utwory z tych burzliwych lat oddają doskonale nastroje wówczas panujące, ale przede wszystkim rysują nam obraz mentalności polskiej szlachty, w której Bógjako surowy Ojciec, Sędzia, ale i Obrońca stale towarzyszy swemu narodowi. To On sprawił, że zewnętrzni nicprzyjaciele nie zdolali wykorzystać slabości skłóconcj Rzeczypospolitej (Seweryn Bączalski, Przestrach śmiertelny). To przede wszysthim Bóg Starego Testamentu, Bóg psalmisty ${ }^{2}$, zdolny pognębić naszych wrogów, ale którego należy przeblagać za grzechy obywateli, aby raczył uratować kraj z otchlani. Pan doświadcza nas jak Izraelitów (Wotum), ale powinien ulitować się nad Rzeczpospolitą, gdyż w niej jest wszak więcej sprawiedliwych niż w Sodomie, za którą wstawial się Abraham (W. Chlebowski, Lamn'nt żatosny Korony Polskiej).

W poezji goracych emocji politycznych, ostro wyrażanych, często pełnych jawnej wrogości uczuć, dość rzadko pojawia się Syn Boży. Jest On przywolywany głównie w utworach o charakterze elegijnym lub tych stylizowanych na pieśni religijne (Elegia postón' splondron'a-

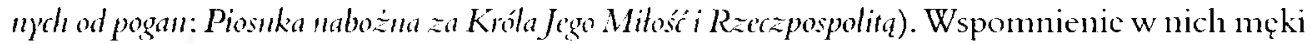
Jezusa Chrystusa ma sankcjonować prośby o zmilowanic i wysłuchanie skarg. Natomiast Kasper Miaskowski nawiązuje do postaci Zbawiciela w zupelıie innyn celu. Buduje analogię między Synem Bożyn a Zygmmntem IIl Wazą, którego wrogowie chcą ukrzyżować (D)alog, albo rozmou'a przyjacitlska o zjezdzit jedrzejou'skim) ${ }^{31 !}$.

W jeszcze innym kontekście imiç Zbawiciela pojawia siç w jednej z rokoszowych pobudek - ma skonsolidować szykujących się do boju i dodać im otuchy. Przypomina się tu Jan Chryzostom Pasck, który podczas szturmowania Koldingu kazal swym zołnierzom wolać "Jezus Maryja” i zlośliwie komentowat, ze choć inni krzyczeli: „hu, hu, hu!”, to on wierzy, ze jemu ,więcej pomoze Jezus niżeli ten jakiś pan I lu” ${ }^{31}$.

Najrzadziej gości na kartach poezji z czasów rokoszu Matka Boska. Moment, gdy staje siç Ona powszechnie uznawaną Królową Polski zaangazowaną w jej losy, jeszcze nie nadszedl ${ }^{32}$.

\footnotetext{
2" Poszczegúlne obrazy rodem z Kisegi Psedmón bez trudu można odnaleźć w tej poezji, a wis rszem. który bezpośrednio wykorzystuje i amplıfikıje wersety psalnowe. jest miçdzy innymi utwór o incipicic Beatus ıir... Zob. też J. Nowak-Dlużewski, Formy religijme staropolskici porzji polityczncj..., s. 176-178.

"Nie jest to jedyne w literaturze rokoszu Zebrzydowskicgo odwolanic do cwangelicznych wydarzeń, oczym szcrzcj pisze J. Nowak-D Duzewski (ibidem. s. 175-176).

${ }^{31}$ J. Ch. Pasck, Pumiętmiki. opr. Wl. Czapliński, Wroclaw 1979 (BN I 62). s. 31.

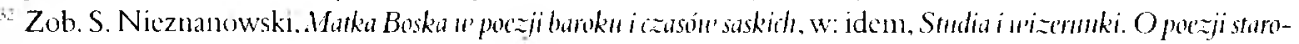
polskiej i joj badaczarh, Warszawa 1989. s. 59-63.
} 
Sporadycznie prosi się Jł o pośreduictwo. Ciekawy jest natomiast ponysł anonimowego autora Wormm zjazdón i rokeszu 1606, od donnatora jednego mapisane. Wedlug nicgo tylko czlowick o szlachetnych zamiarach może zaśpiewać Bogutrodziç i stąd latwo poznać:

[...] komu Bóg wodzem jest, a komu

Diabel we thie hetmani, bo ten tego hasta

Nie wymówi, w kim wiara z myślą prawą zgasła (s. 368).

Znakiem czasu wydaje się być natomiast fakt, ze zamiast Maryi w charakterze opickuna kraju pojawia sic̨ niedawno zmarly hetman Jan Zamoyski. Jenu to dedykowane są następujące slowa:

Ojcze ojczyzny, jeśli miedzy duchy

Swiętymi patrzasz na nasze rozruchy,

Użal się państwa, któregośs ty ciało

Zachowal calo

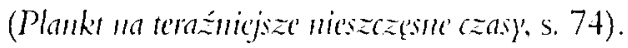

Rzeczpospolita wraz z wydarzeniami rokoszu Zebrzydowskicgo wchodzila w wick dramatycznych konfliktów, tragicznych w skutkach wojen i postępującego rozkładu państwa. Wielı kolejnym pokoleniom poetów przyszło komentować rozgrywające się wypadki, nawotywać do poprawy, karcić wrogów Ojczyzny i powielekroć zwracać się do Najwyższego z prośbą o ratunck, czyniạc z Boga orędownika polskiej sprawy. O ostatecznej katastrofie przesądzili swymi poczynaniami sami rodacy, i w tym kontekście jakże gorzko zabrzmią słowa rokoszowej pobudki:

A nam ludźmi być potrzeba,

Nie wszystko patrząc, co z nieba:

Gidy się przyczyıiemy sami,

Pewnie będzie Pan Bóg z nami

(Piesin rokoszanón animujacych się, s. 116). 